\title{
Assessing Proposals for Mandatory Procedural Protections for Sentencings Under the Guidelines
}

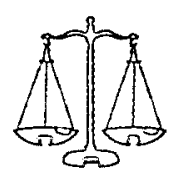

\section{STEVEN D. CLYMER}

Associate Professor of Law, Cornell Law School and Assistant United States Attorney, Northern District of New York. The opinions expressed in this arti. cle are mine, not those of the United States Department of Justice. I thank Frank O. Bow. man, III, Sheri Lynn Johnson, Rory K. Little, Brenda K. Sannes, and David Yellen for their comments on earlier drafts.

\section{A. Introduction}

The federal sentencing guidelines have received sustained criticism from scholars, judges, and practitioners. Critics claim that the guidelines unwisely shift sentencing discretion from federal judges to prosecutors and probation officers; often mandate undeservedly harsh sentences; are complex, mechanistic, and bureaucratic; fail to achieve their goal of reducing sentencing disparity; and clog both district and appellate courts with litigation. ${ }^{\mathrm{I}}$ Despite the attacks, some critics acknowledge that the guidelines will remain in force for the foreseeable future. ${ }^{2}$ While some nonetheless continue to urge abolition, others propose less ambitious reform, including enhancing the procedural protections available to criminal defendants at sentencing. Recommendations include (a) mandatory evidentiary hearings to resolve fact disputes; (b) rights to compel testimony and confront accusers; (c) application of evidentiary rules, particularly the hearsay prohibition, to the prosecution's evidence; (d) use of a standard of proof more rigorous than the "preponderance of evidence" threshold; and (e) pre-plea notice of the govermment's sentencing position. ${ }^{3}$

Critics claim that enhanced procedural protections are needed to ensure the reliability of factual findings at sentencing. Because proposed reforms typically involve providing only defendants with added protections, it appears that the reformers' objective is the reduction of improperly harsh sentences resulting from erroneous determinations of fact. ${ }^{4}$

In addition, some reform proponents contend that the disparity between trial, where there are significant procedural protections, and sentencing hearings, which are less formal, creates an incentive for federal prosecutors to "indict for less serious offenses which are easy to prove and then expand them in the probation office" or at the sentencing hearing itself.' Presumably, an increase in procedural protections at sentencing would both reduce federal prosecutors' motivation to consciously circumvent defendants' trial rights and diminish the disparity between trial and sentencing if prosecutors nonetheless did so.

After a brief description of relevant features of the guidelines, I offer several observations about these proposed measures. ${ }^{6}$ First, although maximizing the reliability of sentencing hearings is a legitimate objective, particularly for factual determinations that have a dramatic impact on the length of sentence, it is not self-evident that the proposed mandatory procedural protections will result in appreciably more accurate fact-finding. Second, in the absence of empirical sup- port, the concern that federal prosecutors might circumvent trial protections is an unpersuasive rationale for restructuring the guidelines sentencing process. Third, some of the proposed reforms impose costs that may offset benefits. At several places below, I propose what may be equally effective and less costly ways to increase reliability, such as greater appellate scrutiny of lower courts' refusals to conduct evidentiary hearings. Finally, I suggest that, if mandatory procedural reforms are adopted, those who believe that they invariably will benefit defendants at sentencing may be disappointed by unintended results.

\section{B. Guidelines Sentencing, Fact Determinations, and Judicial Discretion}

Although the guidelines are frequently criticized for unduly limiting the authority of sentencing courts, in fact, judges applying the guidelines retain significant discretion. The authority of the sentencing court to make findings resolving factual disputes at sentencing is one source of such discretion. Once a judge determines that a particular offense-specific guideline applies, he or she increases or decreases the base offense level for that guideline by resolving factual questions that either are specific to the crime at issue ("specific offense characteristics") or applicable to all sorts of criminal conduct ("adjustments"). Judges engage in similar fact-finding when determining a defendant's criminal history. Resolution of these questions of fact dictates the final offense level and criminal history category, which, in turn, dictate the sentencing range.?

Common factual inquiries at sentencing include determination of the quantity and type of drug; amount of money stolen or laundered; presence or absence of a firearm; whether a defendant played a "minor" or "minimal" role in the offense or was an organizer or supervisor, was involved in "more than minimal planning," "accepted responsibility," "obstructed justice," or committed the offense of conviction "as part of a pattern of criminal conduct engaged in as a livelihood." Judges are supposed to find a disputed fact to be true if the prosecution proves it by a preponderance of the evidence. Because appellate courts show considerable deference to sentencing courts' factual determinations, a sentencing judge inclined to reach a desired outcome under the guidelines often has the ability to do so, or at least come close, by tailoring findings of fact accordingly. Indeed, there are suggestions that some judges are, at times, outcome-conscious when exercising their fact-finding discretion. ${ }^{8}$ 
However the Supreme Court ultimately defines the boundary between elements of crimes and sentencing factors, ${ }^{9}$ it will not eliminate this fact-finding role at sentencing. Even if the Court, as a matter of either constitutional or statutory interpretation, allocates responsibility for resolving particular statutorily-defined facts to juries, as elements of the offenses, rather than to judges, as sentencing factors, there will remain a substantial amount of fact-finding for judges to do at sentencing.

\section{Assessing Proposals for Procedural Reform}

1. Are Mandatory Procedural Protections Necessary to Increase the Reliability of Fact-Finding at Sentencing?

Although not often noted in recommendations for procedural reform, federal judges presently have authority to afford defendants virtually all of the protections that the reformers seek. Probation office pre-sentence reports, affidavits, and prosecution sentencing memoranda often may play a prominent role in judicial resolution of disputed facts at sentencing in the guidelines regime, but nothing requires sentencing judges to rely on those sources of information. ${ }^{10}$ District court judges can order evidentiary hearings on disputed factual issues at sentencing; refuse to find as true any facts not proven at such hearings; permit defendants to present evidence; force confrontation of prosecution witnesses; and reject hearsay evidence as insufficiently reliable to satisfy the prosecution's burden of proof. Because the parties and the probation office frame disputed issues well before the sentencing proceeding, judges have advance notice of the disputed facts and their impact on the sentence, enabling them to determine on a case-bycase basis whether any or all of the protections are warranted at sentencing. Indeed, it is not uncommon for district court judges to afford defendants at least some of the proposed protections when there are disputed issues of fact."

Similarly, sentencing judges have some control over the operation of the burden of proof at sentencing. To be sure, appellate court decisions impose the legal standard to be applied, usually - although not always ${ }^{12}$ - "preponderance of evidence." But standards of proof are imprecise, thus vesting considerable discretion in the fact-finder applying them. Federal judges who act as fact-finders at sentencing have sufficient flexibility in applying the applicable standard to require whatever proof they deem necessary to persuade them of the existence of any guidelines-identified fact. ${ }^{13}$

Thus, the calls for procedural protections are more accurately characterized as demands for the mandatory imposition of such protections in all cases. Herein lies an irony. At the same time that critics bemoan the guidelines' restrictions on federal judges' substantive sentencing authority, some reformers nonetheless advocate drastic limitations on judges' discretion over sen- tencing procedure. Although many guidelines critics are confident that federal judges possess the wisdom, detachment, and experience necessary to apply complex, and often contradictory, theories of punishment to numerous defendant- and crime-specific facts in order to impose appropriate sentences, they apparently question the ability of those same judges to recognize that multiple hearsay in a pre-sentence report may be unreliable, or that evidentiary hearings might assist in resolution of disputed facts.

To be fair, reformers may not question the ability of federal judges to reliably find facts. Instead, they may be concerned that federal district court judges, faced with heavy caseloads and an inordinate number of factspecific guidelines issues, are pressured into reluctantly accepting hearsay in probation reports and from other sources rather than conducting full-blown evidentiary hearings. ${ }^{14}$ Under this view, mandatory procedures are needed to ensure that over-worked judges are forced to afford defendants needed protections in spite of other pressures on their time. Nonetheless, it remains ironic that at least some critics propose to ameliorate what they perceive as the guidelines' unwarranted restraints on substantive sentencing discretion by imposing restrictions on federal judges' procedural discretion at sentencing.

Irony aside, given that judges, not juries, are the fact-finders at sentencing, it is by no means obvious that the proposed procedural protections will produce an appreciable increase in the reliability of fact determinations. Indeed, Professor Stith and Judge Cabranes, two of the most vocal advocates of reform, express doubt "that the fact-finding process in sentencing hearings under the Guidelines is as unreliable as suggested by some critics." "s

Although the rule against hearsay is applicable in bench trials as well as jury trials, restrictions on the use of hearsay evidence are largely a feature of the jury system, and are inextricably linked to a fear that lay juries are unable to properly discount the weight to be given such evidence. ${ }^{16}$ In recognition that judges are better equipped to assess the value of hearsay evidence, the Federal Rules of Evidence typically permit the admission of hearsay in proceedings, including sentencing hearings, where judges sit as fact-finders. ${ }^{17}$ To my knowledge, those who take issue with the present sentencing process have yet to offer a convincing explanation why federal judges are less equipped to properly evaluate hearsay evidence when imposing sentence than in other settings, or why we should require that they conduct fullblown evidentiary hearings in cases in which they are free to do so but have determined it to be unnecessary.

That said, there remain at least two reasons for legitimate concern. First, although many judges may require evidentiary hearings when needed, it is likely that there are others who too readily accept hearsay 
lacking sufficient indicia of reliability. Even fact-finding by experienced judges can, at times, benefit from the full development of factual disputes that cross-examination and presentation of contrary proof provide. Second, under the guidelines, the resolution of a disputed fact may make a drastic difference in the sentence imposed, sometimes more than doubling the term of imprisonment. In cases in which so much is at stake, more process may be warranted even if it yields only a marginal increase in reliability.

However, it does not follow that a blanket imposition of procedural protections is the only available response. A less drastic alternative would be for appellate courts to show less deference to lower courts when reviewing denials of requests for evidentiary hearings and related procedural protections. ${ }^{18}$ Appellate courts could consider both the quality of the evidence presented in connection with a factual dispute and the effect of that resolution on the overall sentence. Whenever the sentencing court relies on suspect evidence to resolve a disputed issue or the resolution has a significant effect on the sentence, appellate courts could more carefully scrutinize a refusal to grant requested process. More rigorous appellate oversight in such cases would not only put sentencing judges on notice of the need to carefully assess requests for evidentiary hearings, it would provide guidance about the circumstances under which such hearings are warranted.

It may also make sense to increase the standard of proof at sentencing to "clear and convincing evidence." To the extent that sentencing judges faithfully apply the "preponderance" standard, 1 it is troubling that we permit an increase in sentence when, at least in theory, the possibility of error is so great. To be sure, as we raise the standard of proof to reduce the possibility of mistaken sentencing enhancements, we also increase the danger of erroneous refusals to impose legally deserved sentences. But, given our traditional commitment to err on the side of protecting the individual from undeserved punishment, even at the cost of somewhat less effective law enforcement, it is easier to justify a standard that results in fewer mistaken sentencing increases than one that errs in the opposite direction. Although such a change might do little to alter the way that judges really resolve cases, ${ }^{20}$ it nonetheless would reflect a commitment to reducing the possibility of unjustly harsh punishment.

\section{Is Reform Necessary to Deter Federal Prosecutors From "Saving Crimes" For Sentencing in Order to Circumvent Trial Rights?}

There is considerable disparity between trial, where a defendant has the right to indictment by grand jury, mandatory pre-trial prosecutorial discovery, suppression of illegally acquired evidence, compulsory process, and confrontation of adverse witnesses, and sentenc- ing, where such rights are largely absent. The same was true before the guidelines, but, whereas judges once had discretion whether to increase a sentence based on conduct other than described in the counts of conviction, federal judges now must take "relevant conduct" into account, even if was not included in the indictment. ${ }^{21}$ The disparity in procedural protections, coupled with mandatory judicial consideration of relevant conduct under the guidelines, creates an incentive for federal prosecutors to refrain from charging related crimes in an indictment and instead "save" them for sentencing in order to circumvent the procedural protections available to defendants at trial.

Although such an incentive may exist, there are reasons to doubt that federal prosecutors behave in this way with any frequency. In many cases, there are no crimes to "save" for sentencing. Disputed factual issues at sentencing often involve matters not chargeable as separate federal offenses, such as the defendant's role in the offense, whether the crime involved more than minimal planning, and the precise amount of money stolen or laundered. Similarly, uncharged relevant conduct may violate only state, not federal, criminal law, thus foreclosing its inclusion in a federal indictment. In those cases, the feared incentive is non-existent, and thus not a sound reason to institute corrective measures.

In cases in which there is evidence of one or more federal crimes that are "relevant" under the guidelines, federal prosecutors have powerful incentives to include the crimes in the indictment, even if doing so activates the defendant's trial safeguards. For example, prosecutors benefit from an increased likelihood of conviction when a jury hears the full range of a defendant's related criminal activities at trial. Because federal joinder rules favor a single trial for related crimes, ${ }^{22}$ a federal prosecutor who includes related criminal conduct in an indictment is almost guaranteed the ability to present it to the jury in a single trial. If, instead, the prosecution waits until sentencing to prove the related conduct, it runs the risk that the jury will never learn of it. Although Rule 404(b) of the Federal Rules of Evidence permits courts to allow the introduction of uncharged "other act" evidence at trial under certain circumstances, the prosecution has no assurance that a court will do so. $^{23}$

In addition, given sentencing courts' fact-finding discretion and the hostility that some federal judges have toward the guidelines, the prosecution may prefer to try to prove the related crimes to a jury beyond a reasonable doubt rather than rely on the chance that the sentencing court will make findings of fact necessary to increase the sentence based on uncharged conduct. If the prosecution earns a conviction, it is assured that the related conduct will play a role at sentencing.

In fact, if the prosecution charges the related conduct in the indictment, rather than saving it for sentencing, it gets two bites of the apple. Under the 
guidelines, sentencing judges can increase sentences based on charged criminal conduct proven by a preponderance of the evidence, even if the charges result in a hung jury or acquittal. ${ }^{24}$ As a result, by including all related criminal conduct in the indictment, the prosecutor has an opportunity to persuade the jury to convict beyond a reasonable doubt, and, if unsuccessful, a second chance to prove the conduct to the sentencing court by a lower standard. In contrast, "saving" related criminal conduct for sentencing limits the prosecution to a single chance to prove it.

In short, although there may be an incentive for federal prosecutors to circumvent a defendant's trial protections by "saving" crimes to be proven at sentencing, the limited opportunities to do so and considerable countervailing incentives make it unlikely that federal prosecutors will behave in that manner. Thus, it is not surprising that critics have not offered evidence that prosecutors employ this strategy. 25

To be sure, there may be rare cases in which prosecutors, acting in good faith, refrain from including charges in an indictment because there is insufficient evidence to prove them beyond a reasonable doubt, but nonetheless offer whatever evidence is available at sentencing because of the lower standard of proof. There is no reason to conclude, however, that such decisions result from a desire to circumvent the procedural protections a defendant would enjoy at trial. Rather, they are the logical outgrowth of the different burdens of proof at trial and sentencing, a difference that pre-dated the guidelines regime.

\section{What Are the Costs of Mandatory Procedural Protections?}

To be meaningful, any discussion of the proposals for mandatory procedural protections should include an assessment of the costs of such changes.

\section{a. Costs of Pre-Plea Notice of Sentencing Facts}

At first blush, it may seem uncontroversial to require prosecutors to provide pre-guilty plea disclosure to defendants of facts relevant to the calculation of the sentence. It is noteworthy, however, that even without such a requirement, the guidelines give defendants significantly more pre-guilty plea notice than was previously available. Pre-guidelines, both the defendant and the prosecution were largely ignorant about what the court would consider relevant at sentencing and what effect any sentencing-relevant matters would have. In contrast, the guidelines give the parties clear notice of both what counts and precisely how much it counts. To the extent that federally-prosecuted defendants now lack notice before guilty pleas, it is only about facts that the prosecution may present at sentencing, not what matters to the court for purposes of imposing sentence.

Although notice of all facts relevant to the guide- lines determination certainly would be useful to a defendant deciding whether to plead guilty, there are difficulties with this proposal. The prosecution often has not discovered all sentencing-relevant facts at the time of a guilty plea. This is particularly true in complex, multi-defendant cases when plea negotiations with some defendants may occur long before completion of the government's investigation. A requirement that prosecutors lock the government into a set of facts at an early stage by giving pre-plea notice might result in undeserved windfalls to defendants who plead guilty before the prosecution has uncovered all evidence relevant to sentencing. Such a requirement might hamper investigations by deterring prosecutors from entering into early plea agreements, which typically involve cooperation, because they are reluctant to be bound to a sentencing position that ultimately may not accurately reflect a defendant's culpability. These concerns may prompt federal prosecutors to require that defendants waive their right to pre-plea notice as a condition of plea agreements, rendering the proposed reform largely meaningless.

Modified versions of the notice requirement also are problematic. ${ }^{26}$ An approach requiring a defendant's consent before permitting prosecutors to present newly discovered evidence at sentencing would do little to remedy the problems described above. Similarly, enabling sentencing courts to consider newly discovered evidence, but not requiring that they do so, would leave both the prosecution and defendant uncertain of the effect of such evidence, undermining the very reason for the pre-plea notice requirement. Also, it would make the effect of newly discovered evidence contingent on the views of individual judges, not the strength or significance of the evidence, thus undermining the guidelines regime. Finally, permitting prosecutors to offer newly discovered evidence, but enabling defendants to withdraw pleas whenever the prosecution does so injects troubling uncertainty into the plea process. ${ }^{27}$ A less troubling alternative would be to entrust to the district court the discretion whether to permit a withdrawal of a guilty plea, which we now do, with guidance from the Sentencing Commission that there should be a presumption in favor of permitting withdrawal whenever previously undisclosed evidence would result in a significant increase in the sentence.

\section{b. Costs of Additional Procedural Protections During Sentencing}

The principal cost of the proposed changes to the sentencing proceeding itself - a required evidentiary hearing, compulsory process, confrontation, and the exclusion of hearsay when there are disputed facts - is the drain on prosecutorial and judicial resources neces. sary to implement the reforms. The costs are significant. It takes a considerable amount of time and 
effort for prosecutors to prepare witnesses and evidence for testimony in court, particularly in complex fraud and drug cases. Similarly, evidentiary hearings can consume hours or days of a trial judge's docket. If we require prosecutors to present testimony from witnesses with personal knowledge and demand that judges have evidentiary hearings with full cross-examination in all sentencings in which there are disputes, we limit the ability of those prosecutors to investigate and prosecute other crimes, and the ability of district court judges to attend to other matters.

By describing those costs, I do not mean to suggest that they outweigh legitimate concerns about the fairness or reliability of the sentencing process, only that they merit consideration. Absent some evidence that the proposed measures will appreciably improve sentencing judges' ability to make accurate fact determinations, or are needed to deter federal prosecutors from circumventing trial safeguards, there is reason to question whether it makes sense to shoulder the costs in all cases in which there is a factual dispute, no matter how insignificant or frivolous. This is particularly true when one considers that the judges who are sitting as factfinders are now free to impose these procedural requirements in cases in which they are warranted.

If mandatory procedures are to be adopted, a better case can be made for a more tailored, less costly response. For example, courts could continue to permit the prosecution, if it chose, to attempt to satisfy its burden with hearsay evidence, such as affidavits or investigative reports, but permit defendants to subpoena and cross- examine the hearsay declarants, as well as present other relevant defense testimony. Such a system would free prosecutors from the burden of preparing and presenting direct examinations in every case involving disputed facts. But, it would enable defendants to contest prosecution evidence when they saw fit to do so. Placing the impetus on defendants to subpoena witnesses would reduce the risk of unnecessary or frivolous litigation. Of course, even in the absence of such defense efforts, judges would still be free to reject or discount hearsay when resolving disputes of fact.

\section{c. Costs of Imposing a More Rigorous Standard of Proof}

Replacing the presently-used preponderance standard with one that requires the prosecution to prove disputed facts by clear and convincing evidence raises fewer concerns than the other proposed reforms. Although such a standard could increase the instances in which courts refused to imposed deserved sentencing increases because the prosecution was unable to satisfy its burden, acceptance of that cost is consistent with our general willingness to be somewhat tolerant of errors that favor freedom over incarceration. In addition, in most cases, it is unlikely that use of that thresh- old will compel prosecutors to expend significantly more time and effort on sentencing than they presently do in order to prove disputed facts by a preponderance of the evidence. Thus, use of the clear and convincing evidence standard would not likely divert substantial prosecutorial or judicial resources that could be used elsewhere.

It is not clear that the same could be said of a greater leap to a "beyond a reasonable doubt" burden for disputed facts at sentencing. Use of that rigorous standard could further increase the number of occasions on which defendants whose conduct warranted an increased sentence would avoid the enhancement only because of a prosecutorial failure to meet the burden of proof. In addition, the high threshold might cause prosecutors to refrain from using reliable hearsay evidence at sentencing, even if it were admissible, and instead opt for live testimony, thus imposing pressure to reallocate prosecutorial resources from other investigations and prosecutions. To be sure, the difference between a "clear and convincing" threshold and a "beyond a reasonable doubt" standard is one of degree. But, given that federal judges, not lay jurors, will apply the standard, the less rigorous burden provides sufficient flexibility to enable judges to reject sentencing increases in cases in which there is any serious doubt about the facts supporting the increase.

\section{Potential Disadvantages for Defendants of Increased Procedural Protections}

It is not clear that increases in procedural protections will be an unmitigated benefit for criminal defendants. Below, I offer three ways in which the proposed reforms might work to the detriment of some defendants. I do so not to demonstrate that the reforms are ill-advised. Rather, I suggest simply that, if successful, those proponents of reform who expect that pro-defendant procedures typically will lead to pro-defendant results may be disappointed by reactions to their proposals.

First, increased procedural protections, such as mandatory evidentiary hearings, may alter the way federal prosecutors bring charges. As a general matter, prosecutors have an aversion to recalling the same witness to testify on several occasions in the same case. Each return visit involves additional work, scheduling concerns, expense, witness inconvenience and reluctance, and the possibility of inconsistent testimony. If faced with regime that requires presentation of live witness testimony at sentencing, this aversion gives prosecutors an incentive to draft indictments more inclusively, including allegations that otherwise might be left for a sentencing hearing. For example, a prosecutor might add overt acts to a conspiracy count in order to guarantee admission of complete witness testimony at trial, rather than go through the difficulty of recalling witnesses at a separate sentencing hearing. Such a prac- 
tice could inure to the detriment of criminal defendants by causing the disclosure at trial of damaging evidence that otherwise might not come to light until sentencing.

The proposed reforms could prompt such prosecutorial behavior even if, as I suggest above, prosecutors already are inclined to include charges describing all related criminal conduct in an indictment. As noted earlier, many potentially disputed sentencing matters involve facts that, standing alone, do not constitute crimes. Thus, even if a general incentive to include all related crimes in an indictment already exists, the proposed reforms could prompt federal prosecutors to include allegations of other sentencing-relevant conduct in indictments, such as the defendant's role in the charged offense or the amount of money stolen or laundered.

Second, even if prosecutors did not add such allegations to indictments, they might seek to avoid return witness difficulties by being more aggressive in their efforts to introduce evidence at trial that, although pertinent to sentencing, is tangentially relevant to guilt. Courts, which are similarly averse to requiring trial witnesses to return for sentencing hearings because of potential scheduling problems, time constraints, and a reluctance to inconvenience witnesses, particularly civilian witnesses, may be more receptive to such evidence than they would be absent a requirement of live witness testimony at sentencing. Again, this could expose the jury to evidence at trial that otherwise would be left for sentencing.

Third, the proposed procedural protections may lead to unintended consequences during the sentencing proceeding itself. As guidelines critics point out, many federal judges are hostile to the guidelines. Often, the hostility is based in part on the belief that the guidelines require unduly harsh sentences. And, as noted above, it appears that at least some federal judges are willing to make factual determinations in a result-oriented fashion, hoping to avoid what they believe to be unjust results that the guidelines would otherwise require.

A formal sentencing process may make it more difficult for such judges to reject evidence that requires increased sentences. It is one thing for a judge to refuse to adopt a conclusory, hearsay-based factual assertion contained in a passage in a probation report or a prosecutor's sentencing memorandum. It is quite another to discount uncontradicted witness testimony during an evidentiary hearing. If reformers succeed in requiring live testimony at sentencing hearings, I suspect that most federal prosecutors will rise to the challenge. If prosecutors perform that job capably, sentencing courts may be less able or inclined to shape sentences by rejecting facts. In addition, if some courts nonetheless continue to do so, prosecutors may be more willing to challenge factual determinations on appeal, particularly when the testimony supporting and increased sentence is uncontradicted.

\section{Conclusion}

By the above discussion, I do not mean to suggest that proposals for procedural reform are ill-advised or should be rejected. Instead, my point is that the desirability of or need for the blanket imposition of mandatory procedural protections is not obvious and the ultimate effects not clear. It may be that some reforms, such as heightened appellate scrutiny of refusals to grant evidentiary hearings, are warranted. Until the more drastic responses are proven necessary, many of the proposed procedural safeguards might be better imposed on a case-by-case basis, depending on both the nature of the evidence presented and its effect on the sentence.

\section{Notes}

I See, e.g., Kate Stith \& Jose A. Cabranes, Fear of Judging: SenTENCING GUIDELINES IN THE FEDERAL COURTS (1998) [hereinafter STITH \& CABRANES, FEAR OF Judging]; Edward R. Becker, Insuring Reliable Fact Finding in Guidelines Sentencing: Must the Guar. antees of The Confrontation and Due Process Clauses Be Applied?, 22 Cap. U. L. Rev. 1 (1993); José A. Cabranes, The U.S. Sentencing Guidelines: Where Do We Go From Here? 12 FED. SENT. RPtr. 208 (2000) [hereinafter Cabranes, Where Do We Go From Here?]; Susan N. Herman, The Tail That Wagged the Dog: Bifurcated Fact-Finding Under the Federal Sentencing Guidelines and the Limits of Due Process, 66 S. CAL. L. REv. 289 (1992); Kate Stith \& José A. Cabranes, Judging Under the Federal Sentencing Guidelines, 91 Nw. U. L. REv. 1247 (1997)[hereinafter Stith \& Cabranes, Judging Under the Guidelines].

Some have defended the guidelines. See, e.g., Frank O. Bowman, III, The Quality of Mercy Must Be Restrained, And Other Lessons in Learning to Love the Federal Sentencing Guidelines, 1996 WIS. L. REV. 679 (1996).

2 See, e.g., Cabranes, Where Do We Go From Here?, supra note 1.

3 See, e.g., Becker, supra note 1, at 21-26; Cabranes, Where Do We Go From Here?, supra note 1.

4 See, e.g., Becker, supra note 1, at 2, 19-20.

5 United States v. Miller, 910 F.2d 1321, 1332 (6th Cir. 1990) (Merritt, C.J., dissenting), cert. denied, 498 U.S. 1094 (1991); see also StITH \& CABRANES, FEAR of Judging, supra note 1 , at 139-40, 158-59; Cabranes, Where Do We Go From Here?, supra note 1; Herman, supra note 1, at 292.

- I do not address claims that due process or other constitu. tional provisions mandate reform. Courts have rejected such claims.

, Judges must impose a sentence within the prescribed range absent grounds for departure.

\& See Stith \& Cabranes, Judging Under the Guidelines, supra note 1 , at 1265 . As Stith and Cabranes note, some judges view "[s]uch manipulation as a lawless exercise of unsanc. tioned power." Id.

- See Apprendi v. New Jersey, No. 99-478 (argued March 28, 2000); Jones v. United States, 526 U.S. 227 (1999); Almen. darez-Torres v. United States, 523 U.S. 224 (1998).

${ }^{10}$ See, e.g., Herman, supra note 1 , at 290-91. The Guidelines mandate only that " $[w]$ hen any factor important to the sentencing determination is reasonably in dispute, the parties shall be given an adequate opportunity to present informa. 
tion to the court regarding that factor." U.S. SENTENCING GUIDELINES MANUAL $\S 6 \mathrm{Al} .3(\mathrm{a})$ (1998). The court is permitted "[ $\mathrm{t}] \mathrm{o}$ consider relevant information without regard to its admissibility under the rules of evidence applicable at trial, provided that the information has sufficient indicia of reliability to support its probable accuracy." /d. at §6A1.3(a) (Policy Statement). The Commentary to that guideline suggests that guidelines sentencing hearings should be more formal than were pre-guidelines sentencings, and that disputes of fact should be resolved with care. However, the Commentary endorses reliance on hearsay, makes clear that evidentiary hearings are not always required, and opts for use of a pre ponderance of the evidence standard.

${ }^{11}$ See Becker, supra note 1, at 5; Herman, supra note 1, at 348 , 354. In the Northern District of New York, where I now prac. tice, such evidentiary hearings are fairly common.

${ }^{12}$ Some appellate courts have opted for a "clear and convincing evidence" standard in unusual situations. See United States v. Watts, 519 U.S. 148, 156, n.2 (1997).

${ }^{13}$ See Jack B. Weinstein, A Trial Judge's Second Impression of the Federal Sentencing Guidelines, 66. S. CAL. L. Rev. 357, 361-63 (1992)(discussing results of informal survey of judicial application of preponderance of evidence standard in guidelines sentencings).

${ }^{14}$ See Herman, supra note 1 , at 355.

${ }^{15}$ Stith \& Cabranes, Fear of Judging, supra note 1 , at 159.

${ }^{16}$ See, e.g., Christopher B. Mueller, Meta-evidence: Do We Need It?, 25 LOY. L.A. L. REv. 819, 822 (1992).

17 See FED. R. EVID. 1101(d)(3).

${ }_{18}$ Professor Herman notes that the prevailing "abuse of discretion" standard, "tend[s] to be forgiving" of district court judges' refusals to conduct evidentiary hearings. Herman, supra note 1 , at 348 .

${ }^{19}$ Apparently judges, at times, apply a higher standard. See Weinstein, supra note 13 , at 360-61.
${ }^{20}$ See Weinstein, supra note 13.

${ }^{21}$ Section 181.3 of the Guidelines gives a complex and broad definition to "relevant conduct," which often can include the commission of crimes other than those charged in the indict. ment. U.S. Sentencing Guidelines Manual § 1B1.3 (1998).

${ }^{22}$ Rule 8(a) of the Federal Rules of Criminal Procedure pro. vides that multiple offenses may be joined in a single indict. ment if they "[a]re of the same or similar character or are based on the same act or transaction or on two or more acts or transactions connected together or constituting parts of a common scheme or plan." FED. R. CRIM. P. 8(a).

${ }^{23}$ To be admitted under Rule 404(b), evidence must be probative of a relevant fact other than the defendant's propensity to commit the charged offense. FED. R. EVID. 404(b). The rule provides some examples of permitted uses: "motive, opportunity, intent, preparation, plan, knowledge, identity, or absence of mistake or accident." / $d$. Even if the other act evi dence satisfied Rule 404(b), the court can nonetheless exclude it as unfairly prejudicial under Rule 403. FED. R. EVID. 403.

${ }^{24}$ See United States v. Watts, 519 U.S. 148 (1997).

${ }^{25}$ Although Stith and Cabranes describe what may be an instance of this sort of charging decision, involving a charged robbery and an uncharged "associated" murder, their description does not make clear whether the federal prosecutor could have charged the murder in a fecieral indict ment. See Stith \& Cabranes, Fear of Judging, supra note 1, at 140.

${ }^{26}$ The modifications discussed in the text are described in detail in Stith \& Cabranes, Fear of Judging, supra note 1, at 160-63.

${ }^{27} / d$. at 162 . 